$\xi=-1$

\title{
Augmenting Drainage System in the Old Town of Kuching, Sarawak, Malaysia
}

\author{
Darrien Yau Seng Mah ${ }^{1}$, Johnny Ong King Ngu', Vernon Liew ${ }^{1}$, Wan Hashim Wan Ibrahim ${ }^{1}$ \\ ${ }^{1}$ Department of Civil Engineering, Faculty of Engineering, Universiti Malaysia Sarawak, 94300 Kota Samarahan, Sarawak, Malaysia \\ *Corresponding author E-mail: ysmah@unimas.my
}

\begin{abstract}
Padungan, one of the busiest business districts within Kuching City has been facing difficulties due to its age and inability to manage urban runoff. To sustain its historical heritage value without compromising the beauty and ability to discharge urban runoff, environmental needs have called for a change in urban stormwater management. The main objective of this study is to incorporate StormPav Green Pavement along the backstreet of Padungan and to investigate the effectiveness of the permeable road. The methodology used in this study is by means of computer modelling using Storm Water Management Model (SWMM). There are two models built, simulating conditions as (a) current drainage system facility; (b) implementing StormPav Green Pavement along the back of Padungan Street for the purpose of accommodating runoff from the whole two rows of buildings. From the analysis of modelling scenes, implementing the permeable road is a preferable solution as it encompasses both the present and future needs into the design consideration.
\end{abstract}

Keywords: Flood; OSD; Permeable road; StormPav; SWMM.

\section{Introduction}

Urban centres, or sometimes known as cities, have higher population density along with various infrastructure features [1]. Such areas support an increasing population growth, which has a significant negative impact on the quality of infrastructures provided [2]. Physical development encourages more paved roads, retarding the process of water dissipation which results in accumulation of surface runoff; when the situation worsens, flooding throughout the area is bound to occur. As stormwater drainage systems play a vital role in dispersing excess water within urban centres, the degradation brings about flash floods, pollution, erosion, sedimentation and other side effects. These phenomena need to be mitigated. To this end, urban water professionals across the globe continually seek and research methods in transitioning current cities into water sensitive cities [3-5].

During the rule of James Brooke, Kuching became the seat of the Brooke government and underwent substantial changes. One of the early founded Padungan area became an important route of Kuching City and remains busy up to this day (Figure 1). Developed in the 1920s, it is inevitable that the urban stormwater drainage system available in Padungan is starting to deteriorate due to its old age. However, in view of the historical heritage value of the commercial properties within Padungan, demolishing them will be a great loss to the local community.

A local newspaper [6] had published an article with this title, "Be serious about solving flash flood in Kuching". It reported repeated instances of critical flash floods in Padungan area (Figure 2), which is the study area. It maintained that the reason for the occurrences of flash floods in this area after pouring rainstorms was due to the lack of good drainage system.
The proposed measure in this study is to have a mock StormPav Green Pavement [7] in the old town of Kuching, namely the Padungan area. The area is not spacious with paved roads and drains. To overcome the constraint of limited land space, we suggest utilising the backstreet behind the shophouses. This seems to be the best option as it will not cause any damage to the old buildings. Moreover, it will not cause disruption to the business activities and traffic flow in Padungan.

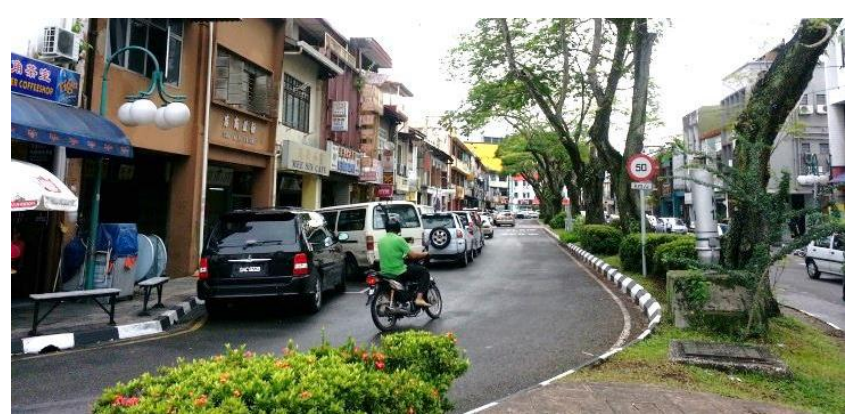

Fig. 1: Padungan Street (photo taken in 2015)

\section{Study Site}

The study area, Padungan was developed in the 1920s, after Sungai Mata Kuching was put into huge canalisation of pipes. It is a well-preserved area consisting mostly of shops that are closely built. It plays a crucial role in accessibility as it connects many roads within Kuching City. In the earlier days, especially during the season of Lunar New Year, Padungan Street would not allow vehicles on its roads. This was due to limited space and for the safety of public, in which shoppers had to walk along the narrow street. However, with the growth in population and vehicles in the later years, this practice was stopped due to severe inconveniences caused to the public. 
Due to the importance of Padungan area, continuous commercial development is required to maintain its functionality as a business district. The health of drainage has been continuously compromised to the extent of causing severe environmental impacts. Padungan area is considered to be fairly large, and thus the study area is kept within two rows of shophouses.

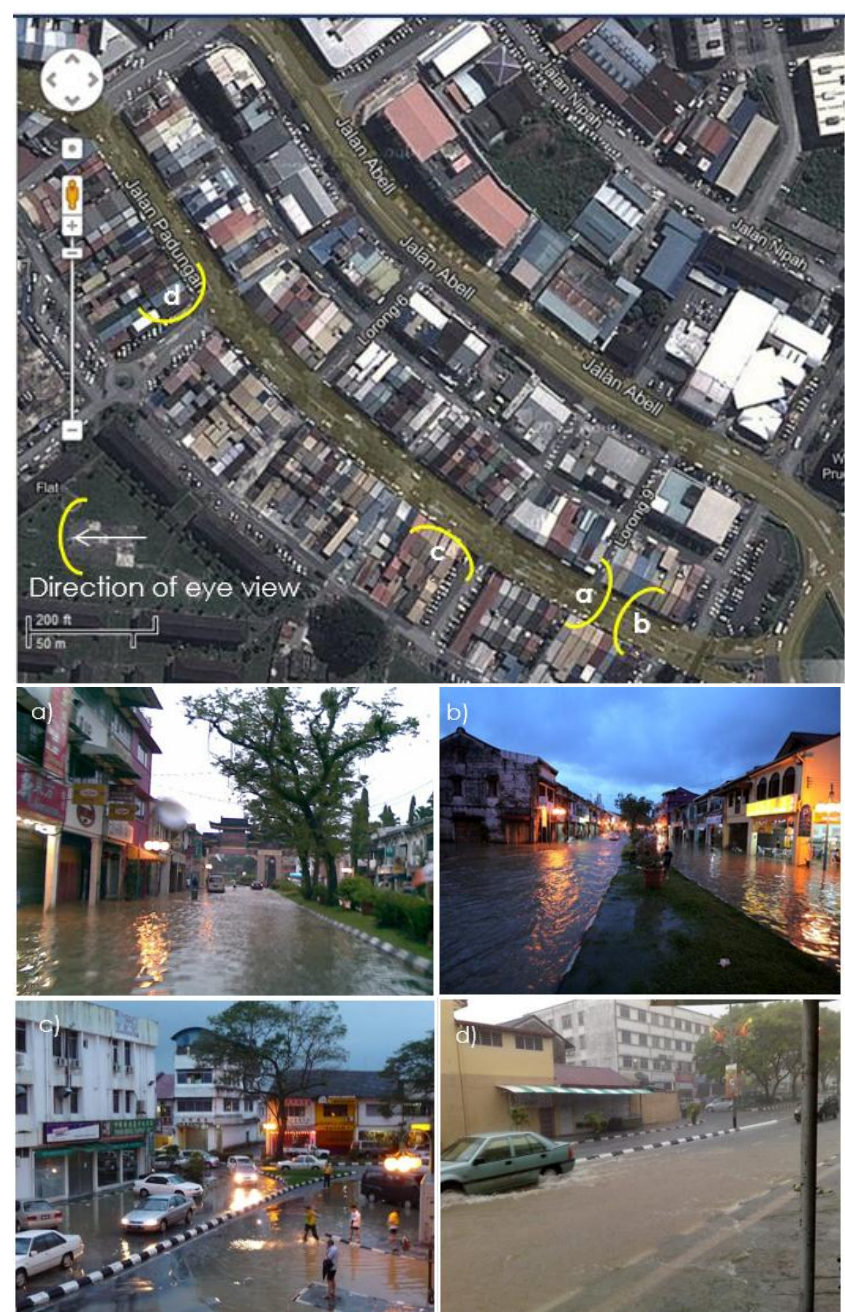

Fig. 2: Aerial Photo of Padungan Area and Incidents of Flash Flood on a) 3 Feb 2009, b) 15 Jan 2009, c) 22 Jun 2013 and d) 4 Jul 2009

\section{Methods}

Referring to the outlined problems mentioned above, a waterproof road could be changed to permeable road. By allowing water storage chambers under the road surface, the function of passing the stormwater could be shared by existing drains and the permeable road [8]. At the same time, the permeable road structure should also be strong enough to support transportation on top of it. The proposed permeable road for Padungan area has to take into consideration that the measure should not disrupt the business activities of the area. Thus, after considering all facts, the best choice is to implement the proposed system in the backstreet of Padungan Street and Abell Street. The system can be viewed in Figure 3. The system is designed to follow the width of the backstreet.

An Industrialized Building System (IBS) named StormPav is introduced here. It consists of three-piece suit to be a single modular unit. The hexagonal plate is used as top and bottom covers, in which the former functions as road pavement with service inlet to drain stormwater; and the latter functions as a raft foundation with service inlet to allow infiltration. Each plate is reinforced by two layers of steel laboratory tested to support up to 10 tonnes of load.

The cylinder unit is hollow in nature to function as storage cell to hold water at a capacity of $0.19 \mathrm{~m}^{3} / \mathrm{m} 2$ of pavement area [9]. Generally, stormwater permeates the road surface to reach storage cells placed under the road pavement (Figure 4). Stormwater could be confined within the system allowing vertical flow of water to underlying soil that the authors opined would have befitted the agenda of sustainability.

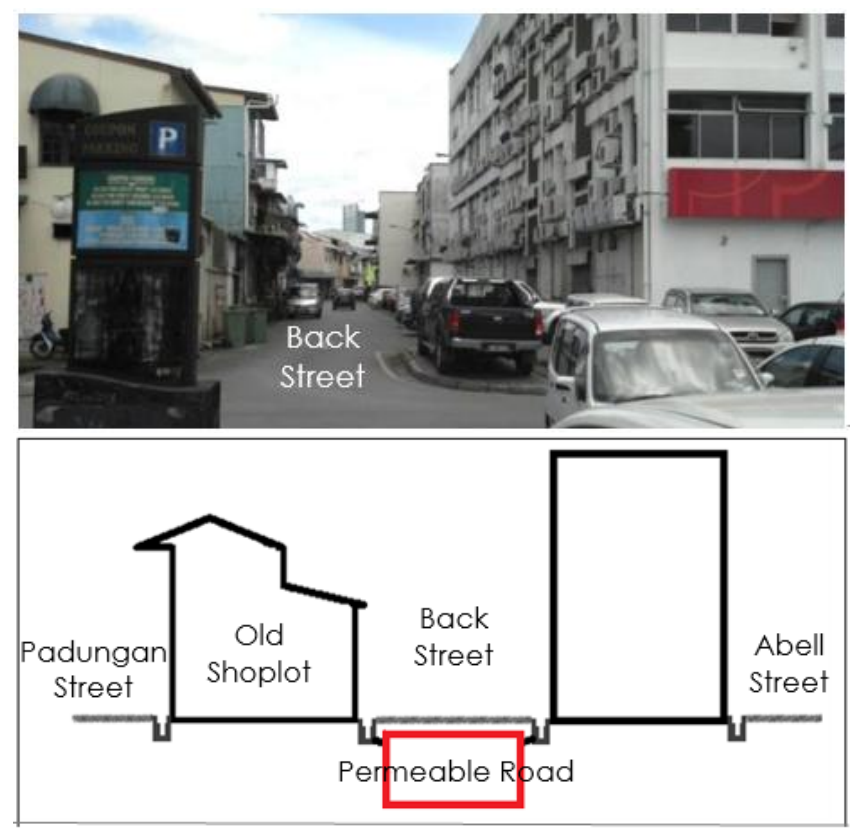

Fig. 3: Proposed permeable road for Padungan area

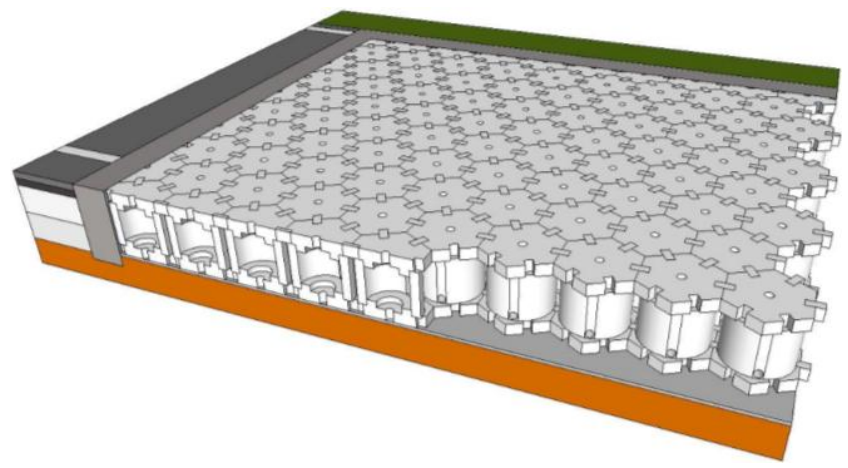

Fig. 4: StormPav green pavement

The purpose of having water storage chamber under the permeable road is similar to have On-Site Detention (OSD) facility [10-11] that is built with a combination of depressions in paved areas for better stormwater conveyance and an underground tank which does not use up land space [12]. Existing gutters, pipes, curbs, and graded surfaces are part of the overall site drainage system which assists in directing stormwater runoff to the StormPav Green Pavement.

Conceptually, rainwater in urban areas is intercepted by roofs and road surfaces. Therefore, roofs and road surfaces become catchments to produce surface runoff. As depicted in Figure 5, catchments are represented as diagonal filled polygons and labelled as $S$ for roof catchments while $\mathrm{R}$ for road catchments. From these catchments, running waters are drained to the nearest stormwater drains. In the case of study area, perimeter drains surround the shophouses. All flows are directed to south-east direction. Drains are represented as junctions (labelled as $\mathbf{J}$ ) and conduits.

\section{Results and Discussion}

To test workability, computer models are created to simulate hydraulic conditions of the study site. Ground information obtained during field visits are incorporated into the base model of conveyance network, and drainage system, within SWMM 5.0. After that, a second conveyance network is generated by adding StormPav 
Green Pavement to the drainage system. With the outputs of simulation, a comparison of results could be done.

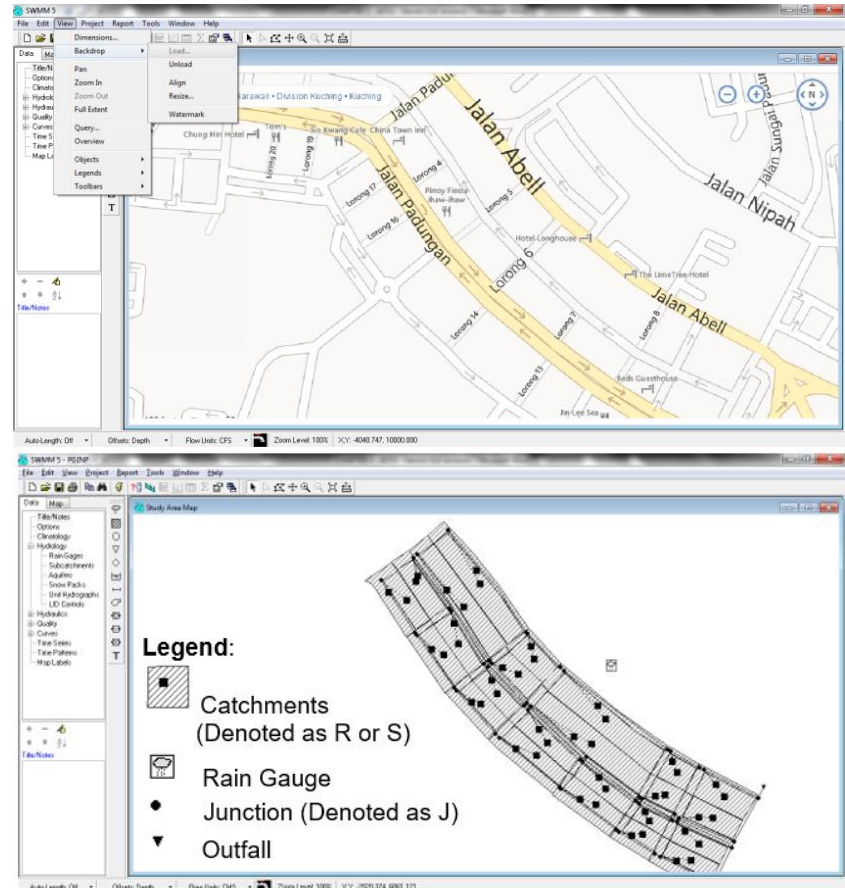

Fig. 5: Conveyance Network with Drainage System

Scenario 1 simulates the rainfall-runoff processes for the existing drainage system along Padungan Street and Abell Street (Figure 6). Due to the nature of the area which is a busy business district, a 15 minute, 10-year ARI design rainfall gives $2-6$ hours of overland flow which is deemed appropriate in our modelling [13].

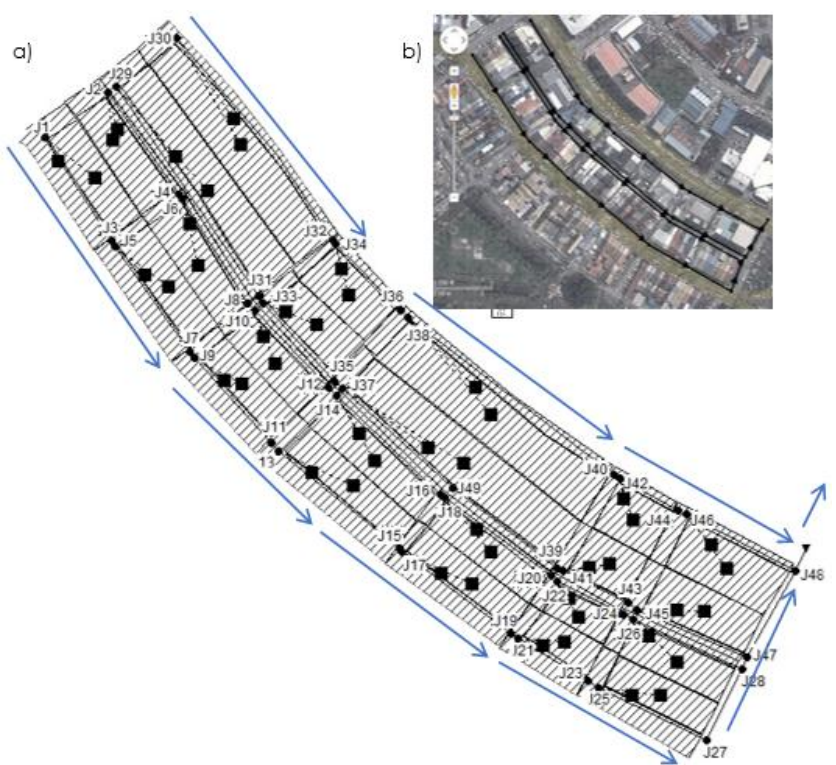

Fig. 6: Scenario 1, a) Modelling of existing drains, b) Existing drains and direction of flow

Through the catchment runoff summary generated by SWMM (Table 1), the peak runoff of the whole catchment is $0.975 \mathrm{~m}^{3} / \mathrm{s}$, which has exceeded the allowed permissible site discharge (PSD), $0.916 \mathrm{~m}^{3} / \mathrm{s}$. In the process of obtaining peak runoff of the whole catchment, hand calculations have some variation from modelling, but it is within an acceptable range.

From node flooding summary (Table 2), the model predicts that the inflow of runoff when confronted by the design rainfall could cause flooding in Junction 25 with a water depth of $0.76 \mathrm{~m}$, which leaves no room for additional runoff intake; Junction 47 with a water depth of $1.0 \mathrm{~m}$ indicates overflowing in Junction 47. No flood is predicted in other junctions.
Table 1: Total Peak Runoff of Padungan Street

\begin{tabular}{|c|c|c|c|c|}
\hline Outfall Node & $\begin{array}{l}\text { Flow } \\
\text { Freq - } \\
\text { Pcnt - }\end{array}$ & $\begin{array}{l}\text { Avg - } \\
\text { Flow } \\
\text { CMS }\end{array}$ & $\begin{array}{l}\text { Max. } \\
\text { Flow } \\
\text { CMS }\end{array}$ & $\begin{array}{r}\text { Total } \\
\text { Volume } \\
10-6 \text { ltr }\end{array}$ \\
\hline 1 & 95.01 & 0.056 & 0.975 & 1.145 \\
\hline System & 95.01 & 0.056 & 0.975 & 1.145 \\
\hline
\end{tabular}

Table 2: Flooding Junction in Scenario 1

\begin{tabular}{|c|c|c|c|c|c|}
\hline Node & $\begin{array}{l}\text { Hours } \\
\text { Flooded }\end{array}$ & $\begin{array}{r}\text { Maximum } \\
\text { Rate } \\
\text { CMS }\end{array}$ & $\begin{array}{r}\text { Time of Max } \\
\text { Occurrence } \\
\text { days } h r: m i n\end{array}$ & $\begin{array}{r}\text { Total } \\
\text { Flood } \\
\text { Volume } \\
10.6 \text { ltr }\end{array}$ & $\begin{array}{r}\text { Maximum } \\
\text { Ponded } \\
\text { Volume } \\
1000 \mathrm{~m} 3\end{array}$ \\
\hline $\mathrm{J} 25$ & 0.06 & 0.008 & $0 \quad 00=31$ & 0.001 & 0.000 \\
\hline J47 & 0.02 & 0.001 & $0 \quad 00: 33$ & 0.000 & 0.000 \\
\hline
\end{tabular}

The setup in Scenario 1 continues to be used in Scenario 2 but with the addition of one unit of Storage Unit (labelled as OSD1) to represent StormPav Green Pavement (Figure 7). The upper-phase shophouses of the study area generate a peak runoff of $0.45 \mathrm{~m} 3 / \mathrm{s}$. By implementing an underground storage unit (Table 3) to accommodate the runoff from the shophouses, with an orifice that limits the storage outflow to $0.088 \mathrm{~m} 3 / \mathrm{s}$, these set ups produce a site discharge of $0.682 \mathrm{~m} 3 / \mathrm{s}$, which is within the limits of permissible site discharge. The mentioned permissible site discharge value allows the estimation of site storage requirement value that enables the sizing of OSD1. The modelling results of Scenario 2 can be viewed in Table 4. It shows that the storage, OSD1, is 95\% occupied, which leaves marginal storage before it overflows. The remaining capacity will be able to accommodate slightly more runoff inflow into the storage in the event of weather variation.

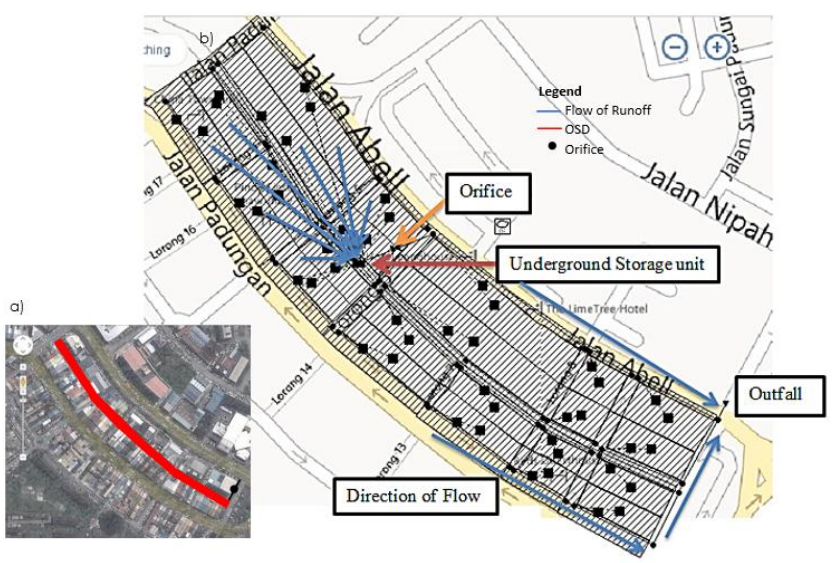

Fig. 7: Scenario 2, a) Location of OSD1, and b) Inclusion of OSD1

\section{Conclusion}

This study has demonstrated the development of a stormwater conveyance model for Padungan area by using SWMM 5.0. Stormwater simulation allows the town planners, local authorities and any other relevant agencies to implement an effective urban stormwater management plan.

All simulations are carried out under 10-year ARI design storm; design storm of a greater magnitude has not been investigated. By analysing the output results of the built stormwater conveyance model, the peak discharge for Scenario 1 is estimated at 0.975 $\mathrm{m}^{3} / \mathrm{s}$. As a result of implementing StormPav Green Pavement by adding underground water storage and a controlled discharge of $0.088 \mathrm{~m}^{3} / \mathrm{s}$ within Scenario 2, there has been a reduction in peak discharge by $30 \%$ to meet the requirement of permissible site discharge. The simulation in Scenario 2 also has shown that $5 \%$ remaining capacity of the underground water storage could be used to cater for weather variability. 
Table 3: Properties of underground storage in Scenario 2

\begin{tabular}{lc}
\hline Storage & OSD1 \\
\hline Length $(\mathrm{m})$ & 280 \\
Width $(\mathrm{m})$ & 3.6 \\
Height $(\mathrm{m})$ & 0.3 \\
Surface Area $\left(\mathrm{m}^{2}\right)$ & 1008 \\
Volume $\left(\mathrm{m}^{3}\right)$ & 302.4 \\
Orifice & 0.088 \\
\hline
\end{tabular}

Table 4: Modelling Results for Scenario 2

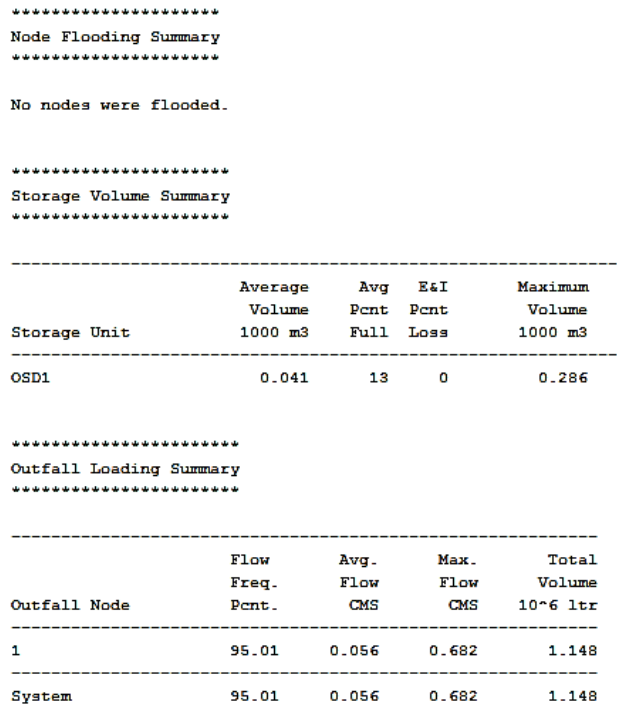

\section{Acknowledgement}

This project was funded by Universiti Malaysia Sarawak via Special Top Down Grant F02/SpTDG/1440/16/3.

\section{References}

[1] Li YF (2010), Urbanization and Global Environmental Change (UGEC) in Hong Kong: Preliminary Survey and Implication for Mainland China.

[2] Queensland Resource Department of Environment and Resource Management (2010), State Planning Policy 4/10: Guideline Healthy Waters. Queensland, Australia.

[3] Brown R (2005), Impediments to integrated urban stormwater management: the need for institutional reform. Environmental Management 36(3), 455-468.

[4] Brown R, Clarke J (2007), The Transition towards Water Sensitive Urban Design: The Story of Melbourne, Australia. Report No 07/01, Facility for Advancing Water Bio-filtration, Monash University, Clayton, Victoria.

[5] Brown R, Keath N, Wong T (2008), Transitioning to Water Sensitive Cities: Historical, Current and Future Transition States. Melbourne, Australia

[6] Borneo Post Online (2013), Be Serious about Solving Flash Flood in Kuching, April 3, 2013. Retrieved on September 2, 2013 from http://www.theborneopost.com.

[7] Mannan MA, Bateni N, Teo DCL, Mah YS, Putuhena FJ, Ng CK Bustami RA, Ibrahim WHW, Lee CLF, Lim HL (2016), StormPav, System and Method of Green Pavement. Application Number PI2016704420. MyIPO, Kuala Lumpur, Malaysia.

[8] Mah DYS (2016), Potential of Road Subsurface On-Site Stormwater Detention System. ISBN 978-969-2008-05-7. UNIMAS Publisher, Kota Samarahan, Sarawak, Malaysia.

[9] Ngu JOK, Mah DYS, Bong CHJ (2016), Flow characteristics of individual lot stormwater detention. Water Practice and Technology 11(4), 721-727.

[10] Beecham S, Kandasamy J, Khiadani M, Trinh D (2005), Modelling on-site detention on a catchment-wide basis. Urban Water Journal 2(1), 23-32.

[11] Van der Sterren M, Rahman A, Shrestha S, Barker G, Ryan G (2009), An overview of on-site retention and detention policies for urban stormwater management in the Greater Sydney region in Australia. Water International 34(3), 362-372.
[12] Van der Sterren M, Rahman A (2015), Single Lot On Site Detention Requirements in New South Wales Australia and its Relation to Holistic Storm Water Management. Sustainability of Water Quality and Ecology. Available online 13 January 2015.

[13] Malaysian Department of Irrigation and Drainage (DID) (2012), Urban Storm Water Management Manual for Malaysia or Manual Saliran Mesra Alam (MSMA), 2nd Edition. Percetakan Nasional, Kuala Lumpur, Malaysia. 